\title{
A new genus and new species of corinnid spiders (Aranei: Corinnidae) from Southeast Asia
}

\section{Новый род и новый виА пауков-кориннид (Aranei: Corinnidae) из Юго-Восточной Азии}

\author{
Jianying Fu ${ }^{1}$, Feng Zhang ${ }^{2 *} \&$ Jomo MacDermott ${ }^{3}$ \\ Ц. Фу, Ф. Жань, А. МакАермотт
}

College of Life Sciences, Hebei University, Baoding Hebei 071002, China. E-mail:fujianying008@126.com²; dudu06042001@ 163.com²; joekelly82@gmail.com ${ }^{3}$

* corresponding author

KEY WORDS: Abdosetae hainan, new genus, new species, new combination, China, Malasia.

КЛЮЧЕВЫЕ СЛОВА: Abdosetae hainan, новый род, новый вид, новая комбинация, Китай, Малайзия.

ABSTRACT. The corinnid genus Abdosetae gen.n., is erected and described, with Abdosetae hainan sp.n. from Hainan Province, China, as its type species. Detailed characters of the genus are provided. One new combination is established: Abdosetae ornata (Deeleman-Reinhold, 2001) comb.n. ex. Otacilia.

РЕЗЮМЕ. Описан новый род пауков Abdosetae gen.n. с типовым видом Abdosetae hainan sp.n. из острова Хайнань. Приведена детальная характеристика рода. Установлена новая комбинация : Abdosetae ornata (Deeleman-Reinhold, 2001) comb.n. ex. Otacilia.

\section{Introduction}

The spider family Corinnidae currently contains 81 genera and 956 species worldwide [Platnick, 2010]. At present 10 genera containing 48 species are reported from China [Song et al., 1999; Zhang et al., 2009 a,b]. Corinnidae is currently subdivided in four subfamilies: Phrurolithinae, Corinninae, Castianeirinae and Trachelinae [Bosselaers \& Jocqué, 2002]. The definition of the Phrurolithinae was broadened somewhat by Deeleman-Reinhold [2001] to include peripheral South Asian genera, for example, Sesieutes Simon, 1987, Jacaena Thorell, 1897, Teutamus Thorell, 1890, Sphingius Thorell, 1890, Otacilia Thorell, 1897, Sudharmia Deeleman-Reinhold, 2001, Plynnon Deeleman-Reinhold, 2001 and Orthobula Simon, 1987. Platnick [2010] listed some of them still in the family Liocranidae, following Bosselaers \& Jocqué [2002].

While examining spider specimens collected in 2009 from Hainan Island, China, we found two specimens that belong to the subfamily Phrurolithinae as defined by Deeleman-Reinhold [2001]. The male abdomen is ventrally ornamented with a double, longitudinal row of long setae just posterior to the genital fold, and has a tuft of bristles in anterior to the spinnerets. The male palpal femora are not visibly modified ventrally, but are somewhat compressed laterally and keeled. The leg femora have no dorsal macrosetae. The PME are not reduced in size. As no known corinnid genus has this combination of characters, we describe here a new corinnid spider genus, Abdosetae gen. nov., with the type species, Abdosetae hainan, sp. nov.

In addition, the species, Otacilia ornata DeelemanReinhold, 2001, is newly transferred from Otacilia to Abdosetae gen.n., comb.n.

\section{Materials and Methods}

Terminology is standard for Araneae. All measurements given are in $\mathrm{mm}$. Carapace length was measured from the anterior margin to the rear margin of the carapace medially; total length is the sum of carapace and abdomen length, regardless of the petiolus. Eye sizes were measured as the maximum diameter in dorsal or frontal view. The measurements of legs are as follows: total length (femur + patella plus tibia + metatarsus + tarsus). All specimens are preserved in $75 \%$ ethyl alcohol and were examined, drawn and measured under a Nikon SMZ1500 stereomicroscope. Epigyne were removed and cleared in $10 \%$ warm solution of potassium hydroxide $(\mathrm{KOH})$, transferred to alcohol and temporarily mounted for drawing. Type specimens of new species are deposited in the Museum of Hebei University (MHBU), Baoding, China.

The following abbreviations are used: ALE - anterior lateral eyes; AME — anterior median eyes; AER - anterior eye row; MOA — median ocular area; PER - posterior eye row; PLE - posterior lateral eyes; PME — posterior median eyes; PMS — posterior median spinnerets; RTA — retrolateral tibial apophysis. 


\section{Taxonomy}

\section{Abdosetae gen.n.}

Type species: Abdosetae hainan sp.n.

ETYMOLOGY. This genus takes its name from the abdominal setae and is a contraction of the words "abdominal setae", feminine in gender.

DIAGNOSIS. This new genus, Abdosetae gen.n., resembles Otacilia, but the new genus differs from the latter by: (1) male abdomen ventrally ornamented with a double longitudinal row of long setae, just posterior to the genital fold; and with a tuft of bristles anterior to the spinnerets; while the latter without longitudinal row of long setae and a tuft of bristles; (2) tarsi almost as long as metatarsi in both sexes, while Otacilia often with longer metatarsi; (3) male palpal femora not visibly modified ventrally, only somewhat compressed laterally and keeled, while Otacilia often with distinct knob-shaped apophysis and compressed; (4) PME not reduced and close to laterals, while in Otacilia often oval or reduced; (5) anterior femora without any dorsal spine, while Otacilia usually with 1 short dorsal spine.

DESCRIPTION. Small spiders, 2-4 long, body orange-yellow to brown with pattern. Carapace low, with smooth surface, elongate-ovoid in dorsal view, bulging, highest near dorsal groove, widest at coxae II and III; dark yellow or brown, usually darker in eye area; cephalic groove and radial furrow brown; thoracic groove short, longitudinal. Eyes moderately large, arranged in two transverse rows. From above, AER slightly recurved, PER wider than AER and recurved, AME size variable and close to ALE, PME separated, not reduced in size, and close to PLE (Fig. 6); Chelicerae moderately long, brown and with $2-3$ promarginal and 2-5 retromarginal teeth; with two pairs of spines frontally, one pair short and the other pair longer. Chilum obsolete. Endites longer than wide (4/3), convex on lateral margin, obliquely depressed; labium broad, rebordered, round distally; sternum truncate at front, pointed behind, with strongly rebordered margins. Leg IV longer than leg I, leg formula: 4123. Tarsi almost as long as metatarsi. Legs brown, all femora without a dorsal spine, only with a row of ventral spines. The anterior tibiae and metatarsi each with a series of very strong paired spines ventrally; the posterior legs are spineless.

Abdomen ovoid, yellowish, a dorsal narrow scutum situated anteriorly in males. Colulus lacking. In males, abdomen ventrally ornamented with a double longitudinal row of long, stiff setae, just posterior to the genital fold, and with a tuft of bristles anterior to the spinnerets. In females, PL spinnerets with distal conical segment, small, with a few spigots with enlarged base; PMS enlarged, laterally compressed and with 2 parallel rows of atypical cylindrical gland spigots.

Male palpus (Figs 9-11) with large, forked retrolateral tibial apophysis, one fork extending posteriorly, and femur without a hump on ventral side, only slightly compressed laterally and keeled. Tegulum convex, without conspicuous apophysis; embolus spine-shaped, relatively long, erect, situated at tip of tegulum; sperm duct short, thick and distinct.

Epigynum with two round copulatory openings, situated centrally; anterior bursae large, balloon-shaped; spermathecae smaller and kidney-shaped, located at lower part of the epigynum; a short connecting tube between the anterior bursae and posterior spermathecae.

COMPOSITION. Abdosetae ornata (DeelemanReinhold, 2001) and A. hainan sp.n.

DISTRIBUTION. China (Hainan) and Malaysia.

\section{Abdosetae hainan sp.n.}

Figs 1-11.

TYPE MATERIAL. Holotype male (MHBU), CHINA: Hainan Province, Mt. Diaoluo $\left(18.87^{\circ} \mathrm{N}, 109.83^{\circ} \mathrm{E}\right), 6$ June 2009 , collected by Chao Zhang. Paratypes: one female, collected by Guangxin Han, same data as holotype (MHBU).

ETYMOLOGY. The species name is a noun in apposition, derived from the type locality.

Diagnosis. This new species resembles A. ornata in the shape of the male genital organs, but can be distinguished from those of $A$. ornata by: (1) embolus spineshaped, relatively longer than that of $A$. ornata; (2) male with dorsal narrow abdominal scutum, while that of $A$. ornatais without scutum; (3) shape of the retrolateral tibial apophysis differs from that of A. ornata ; (4) tegulum convex, without conspicuous apophysis, while that of $A$. ornata has a spine-shaped tegular apophysis.

DESCRIPTION. Male. Holotype total length 1.82; carapace 1.04 long, 0.91 wide; abdomen 0.78 long, 0.65 wide. Carapace pale yellow in the centre, dark grey in the periphery, mouthparts and sternum pale yellow, chelicerae suffused with dark grey. Carapace elongate-ovoid in dorsal view, bulging, highest almost at dorsal groove, widest at coxae II and III; dark yellow or brown, usually darker in eye area; cephalic groove and radial furrow brown; thoracic groove short, longitudinal. Eyes moderately large, arranged in two transverse rows. From above AER slightly recurved, PER slightly wider than AER and recurved (Fig. 1); eye diameter: AME 0.08, ALE 0.07, PME 0.07, PLE 0.08; eye interdistances: AME-AME 0.09, AME-ALE 0.08, PME-PME 0.13, PME-PLE 0.08, ALE-PLE 0.08; MOA 0.20 long, anterior width 0.13 , posterior width 0.16 . Clypeal height 0.10 . Chelicerae moderately long, brown and with two promarginal and five retromarginal teeth; with two pairs of spines frontally, one pair short and the other pair longer. Endites longer than wide (4/3), convex on lateral margin, obliquely depressed, greatly narrowed at palpal insertion; labium broad, rebordered, round distally; sternum truncate at front, pointed behind, with strongly rebordered margins. Measurements of legs: I $3.69(1.08+0.27+0.99$ $+0.81+0.54)$, II $3.18(0.85+0.25+0.87+0.76+$ $0.45)$, III $2.65(0.76+0.23+0.59+0.67+0.40)$, IV $3.84(1.13+0.41+0.94+0.86+0.50)$. Leg formula: 

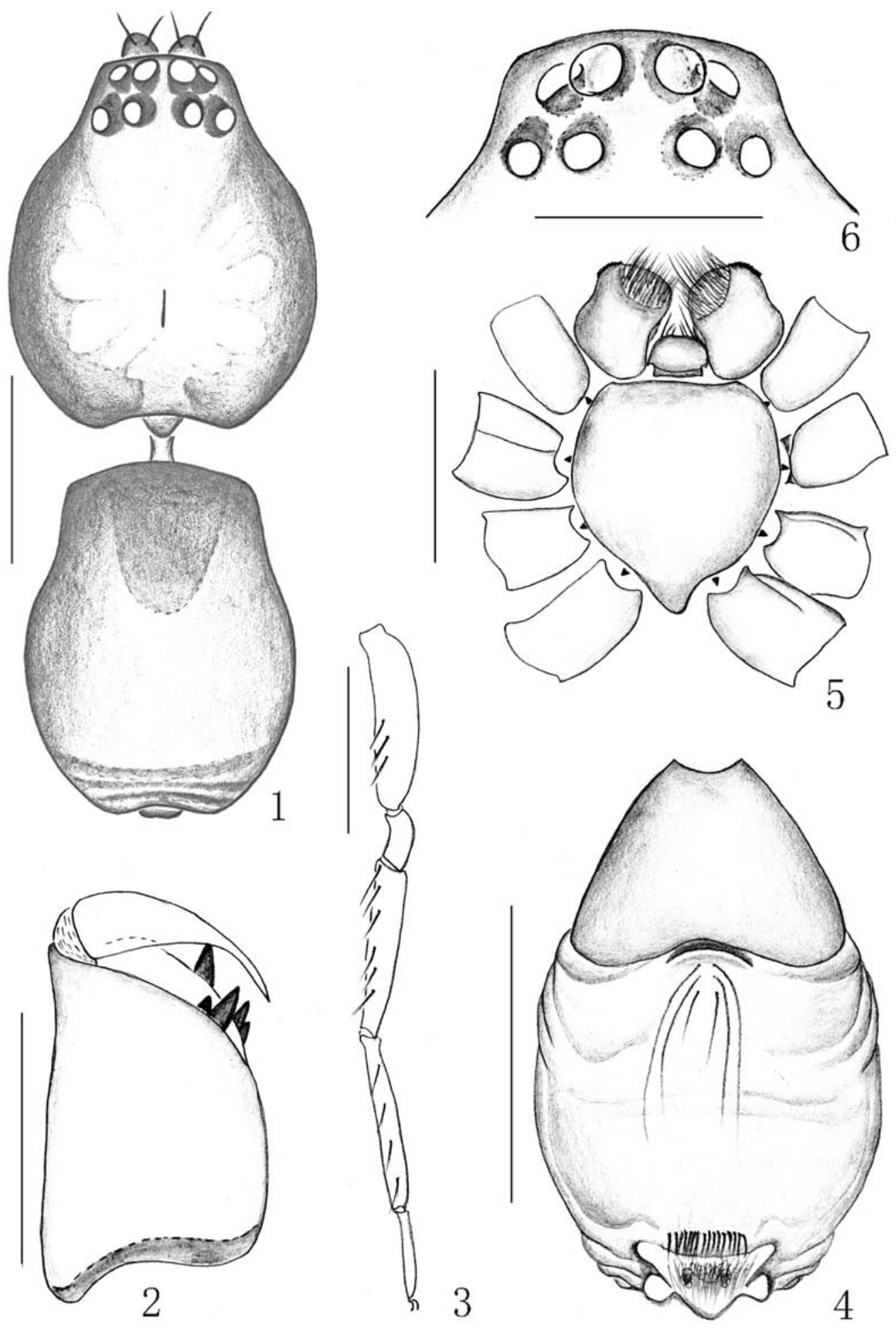

Figs 1-6. Abdosetae hainan sp.n.: 1 - male body, dorsal view; 2 - right chelicera of male, posterior view; 3 - male left femur, patella, tibia, metatarsus and tarsus I, lateral view, showing spines; $4-$ male abdomen, ventral view; 5 - endites, labium and sternum of male, ventral view; 6 - eye region of male, dorsal view. Scale bars: $0.5 \mathrm{~mm}(1,3-6) ; 0.3 \mathrm{~mm}(2)$.

Pис. 1-6. Abdosetae hainan sp.n.: 1 - габитус самца, сверху; 2 - правая хелицера самца; 3 - нога I сбоку, показано шипование; 4 - брюшко самца, снизу; 5 - максиллы, нижняя губа и стернум самца, снизу; 6 - глазное поле самца, сверху. Масштаб: 0,5 мм (1, 3-6); 0,3 мм (2). 

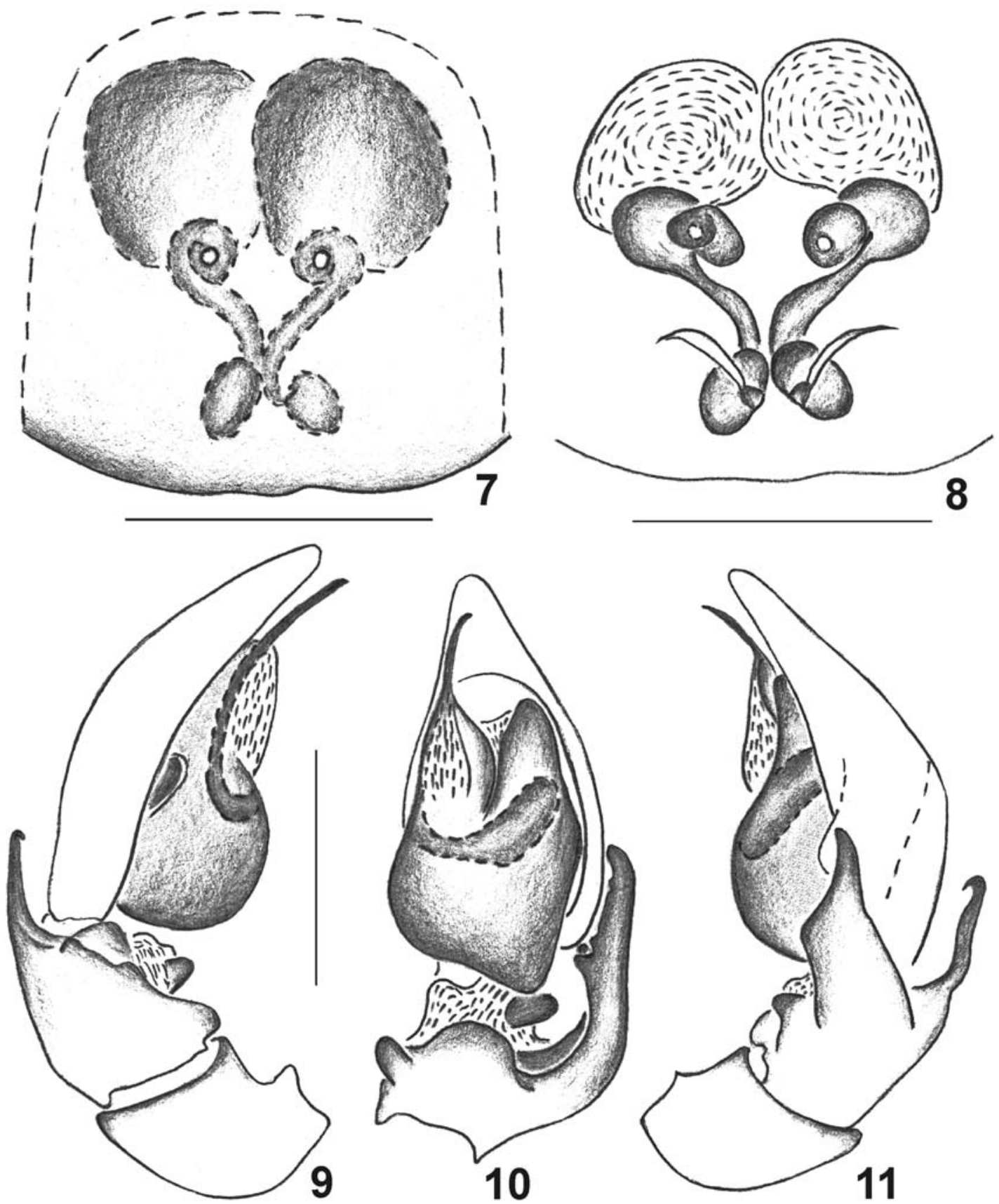

Figs 7-11. Abdosetae hainan sp.n.: 7 - epigynum, ventral view; 8 - vulva, dorsal view; 9 - male left palp, prolateral view; $10-$ same, ventral view; 11 - same, retrolateral view. Scale lines: $0.5 \mathrm{~mm}$.

Рис. 7-11. Abdosetae hainan sp.n.: 7 - эпигина, снизу; 8 - вульва, сверху; 9-11 - левая пальпа самца, пролатерально, вентрально и ретролатерально. Масштаб: 0,5 мм.

4123. Legs brown, femur I with three spines ventrally; tibia I with six pairs of ventral spines; metatarsus I with four pairs of ventral spines; tibia II with six pairs of ventral spines, metatarsus II with three pairs of spines; other segments without spines.

Abdomen ovoid, yellowish, a dorsal narrow scutum anteriorly situated. Colulus lacking. Abdomen ventral- ly ornamented with a double longitudinal row of long, stiff setae, just posterior to the genital fold and with a tuft of hair anterior to the spinnerets. Male palpus (Figs 9-11) with large, forked retrolateral tibial apophysis one fork extending posteriorly, and femur without a hump on ventral side. Tegulum convex, without conspicuous apophysis; embolus spine-shaped, relatively 
long, erect, situated at tip of tegulum; sperm duct short, thick and distinct.

Female. Paratype total length 2.33. Carapace 1.12 long, 0.90 wide; abdomen 1.21 long, 0.85 wide. Carapace colour, eye arrangement, abdominal colouration as for male. Clypeal height 0.10. Eye diameter AME 0.09, ALE 0.08, PME 0.08, PLE 0.09. Distance AMEAME 0.10, AME-ALE 0.09, PME-PME 0.15, PMEPLE 0.10, ALE-PLE 0.16. MOA 0.15 long, front width 0.16 , back width 0.19. Leg measurements: I $3.79(1.10+$ $0.29+1.01+0.83+0.56) ;$ II $3.29(0.87+0.27+0.90+$ $0.78+0.47)$; III $2.75(0.78+0.25+0.60+0.69+$ $0.42)$; IV $3.54(1.05+0.33+0.96+0.78+0.52)$. Leg formula: 4123. Legs brown, femur I with three spines; tibia I with six pairs of ventral spines; metatarsus I with four pairs of ventral spines; femur II with two spines ventrally, tibia II with five pairs of ventral spines, metatarsus II with four pairs of spines; other segments without spines.

Abdomen and legs less contrastingly coloured, without abdominal rows of ventral setae or pre-spinneret tuft. PMS enlarged, laterally compressed and with two parallel rows of atypical cylindrical gland spigots.

Epigynum as illustrated (Figs 7-8). Epigynum with two round copulatory openings, situated centrally; anterior bursae large, balloon-shaped; spermathecae smaller and kidney-shaped, located at lower part of the epigynum; a short connecting tube between the anterior bursae and posterior spermathecae.

DISTRIBUTION. Presently known only from the type locality, Hainan, China.

Abdosetae ornata (Deeleman-Reinhold, 2001), comb.n. $\left(\mathrm{O}^{\mathrm{T}}+\mathrm{O}^{+}\right)$.

Otacilia ornata Deeleman-Reinhold, 2001: 420, f. 675-680

NOTE. Deeleman-Reinhold [2001] placed Otacilia ornata (collected from Kinabalu area in western Sabah, Malasia), into Otacilia, mainly because the anterior legs of this species have many pairs of spines ventrally, and the chelicerae have two pairs of spines; but some of the characters are different from other species of Otacilia, as she stated: “...easily distinguished by the contrasting pattern of the carapace and abdomen, the large tibial apophysis with additional dorsal branch and the shape of the embolus and tegular apophysis in the male palp. Furthermore, in males there is a double row of long hair ventrally on the abdomen; in the epigyne the shape and position of the spermathecae are diagnostic.". All these characters are very particular and different from other Otacilia species, but they fit the characters of Abdosetae gen.n. found in this paper. Therefore, according to her illustration and description, we newly transfer this species from Otacilia to Abdosetae gen.n.

ACKNOWLEDGEMENTS. We are grateful to Drs Chao Zhang and Guangxin Han for collecting type specimens. Dr Yuri M. Marusik kindly helped reviewing the manuscript. A special thanks is extended to Jan Bosselaers and Martin Ramirez, two referees for their critical review of the manuscript and helpful suggestions. This work was supported by the National Natural Science Foundation of China (No. 30499341), and in part by the Doctoral Program Foundation of Institutions of Higher Education of China (No. 20091301120005) to Dr Feng Zhang.

\section{References}

Deeleman-Reinhold C.L. 2001. Forest spiders of South East Asia: with a revision of the sac and ground spiders (Araneae: Clubionidae, Corinnidae, Liocranidae, Gnaphosidae, Prodidomidae and Trochanterriidae). Leiden: Brill. 591 pp.

Bosselaers J., Jocqué R. 2002. Studies in Corinnidae: cladistic analysis of 38 corinnid and liocranid genera, and transfer of Phrurolithinae // Zool. Scripta. Vol.31. P.241-270.

Platnick N.I. 2010. The world spider catalog, version 10.0. American Museum of Natural History, online at http://research.amnh. org/entomology/spiders/catalog/index.html. (Accessed 15 January 2010)

Song D.X., Zhu M.S., Chen J. 1999. The Spiders of China. Shijiazhuang: Hebei Science \& Technology Publishing House. $640 \mathrm{pp}$.

Zhang F., Fu J.Y., Zhu M.S. 2009a. A new species of the genus Otacilia (Araneae: Corinnidae) from Yunnan Province, China // Acta arachnologica. Vol.58. No.1. P.1-3.

Zhang F., Fu J.Y., Zhu M.S. 2009b. A review of the genus Trachelas (Araneae: Corinnidae) from China // Zootaxa. No.2235. P.40-58. 